\title{
KAJIAN KESEJAHTERAAN HARIMAU SUMATERA PADA KONSERVASI EX-SITU DI TAMAN MARGASATWA RAGUNAN DAN TAMAN MARGASATWA BANDUNG
}

\author{
Studying animal welfare of Sumatran tiger to conservation ex-situ activity on the ragunan zoo \\ and Bandung zoo
}

\author{
Yolanda, Rusdi, Atin supiyani \\ Program studi Biologi, Fakultas Matematika dan Ilmu Pengetahuan Alam \\ Correspondency Email: Atinsupiyani@gmail.com
}

\begin{abstract}
A zoo is one of an ex-situ conservation activity whice aimed to conserve plants and wildlife animal an endangered position, for example; the Panthera tigris sumatrae population are decrease. The zoo were succeed to captivate an animal only if they can adopt their normal life into that place. The aim of this research was to study the animal welfare from Sumatran tiger in two different places; Bandung zoo and Ragunan zoo. This research has been conducted in Desember - February 2017. The research method that are used in this study were interviewed and filling draft animal welfare from Indonesian Ministry of Forest No.P.9/VI-SET/2011. The Result of this research were $77 \%$ point for Ragunan zoo and $60 \%$ point for Bandung zoo which different mean both of that place. Filling draft animal welfare consist beside five freedom of animal welfare; 1). Freedom from hunger and thirst, 2). Freedom from discomfort, 3). Freedom from injury, paint, and disease, 4). Freedom to express natural behavior, 5). Freedom from fear and distress. The conclusion of this research were Ragunan zoo was better than Bandung zoo to applied animal welfare rules.
\end{abstract}

Keywords: Sumatran tiger, Animal Welfare, Conservation, Zoo.

\section{PENDAHULUAN}

\section{LATAR BELAKANG}

Harimau Sumatera atau Panthera tigris sumatrae dikenal sebagai predator alami, namun keberadaannya terancam punah. Jumlah populasi harimau Sumatera dari tahun ke tahun semakin menurun. Pada tahun 1978 diperkirakan 1000 ekor (Borner, 1978). Pada tahun 2007 hanya tersisa 250 ekor harimau Sumatera yang hidup di taman nasional dan hutan lindung (Departemen Kehutanan Indonesia, 2007).

Kepunahan harimau Sumatera dapat mengganggu stabilitas ekologi. Kepunahan harimau Sumatera disebabkan karena adanya kegiatan deforestasi hutan, perburuan liar harimau, perburuan liar hewan selain harimau, dan konflik yang terjadi antara harimau dan manusia (Wibisono, 2010), depopulasi harimau Sumatera pada kawasan konservasi 
ex-situ terjadi karena ketidakseimbangan pakan yang diberikan, tidak dapat mengekspresikan perilaku dengan bebas, hewan menjadi stres, kandang hewan yang tidak bersih, dan masih banyak hal-hal yang menjadi faktor berkurangnya populasi harimau Sumatera. Oleh karena itu perlu adanya upaya konservasi bagi populasi harimau Sumatera yang melibatkan berbagai pihak, seperti pemerintah, lembaga konservasi, baik nasional maupun internasional. Peran aktif masyarakat juga diperlukan untuk menjaga keberlangsungan hidup harimau Sumatera dalam menjaga dan melindungi populasinya dari kepunahan.

Salah satu upaya pelestarian harimau Sumatera adalah dengan adanya kegiatan konservasi. Konservasi harimau Sumatera dapat dilakukan secara ex-situ dan in-situ. Konservasi in-situ merupakan usaha pelestarian yang dilakukan di habitat aslinya, dan konservasi $e x-s i t u$ adalah usaha pelestarian yang dilakukan di luar habitatnya (Peraturan Pemerintah, 2012). Salah satu bentuk konservasi yang ada di Indonesia yaitu dengan mendirikan Taman margasatwa dan salah satu tujuan dibentuknya lembaga konservasi adalah mengadakan kegiatan pelestarian harimau Sumatera. Dalam perkembangannya, kegiatan konservasi harus terus ditingkatkan dan dievaluasi, indikator dari keberhasilan konservasi dilihat dari peningkatan jumlah harimau yang bertahan hidup dan mampu berkembang biak tergantung pada tingkat kesejahteraan hidupnya.

\section{MANFAAT PENELITIAN}

Dari penelitian ini dapat menjadi sumber informasi dan bahan acuan bagi penelitian selanjutnya dan menjadi bahan pertimbangan bagi pengelola taman margasatwa dalam mengoptimalkan usaha kesejahteraan satwa.

\section{RUANG LINGKUP PENELITIAN}

Penelitian hanya dibatasi untuk mengetahui kegiatan konservasi kesejahteraan satwa pada harimau Sumatera di TM Ragunan dan TM Bandung .

\section{METODOLOGI PENELITIAN}

\section{TEMPAT DAN WAKTU}

Tempat penelitian dilakukan di taman Margasatwa Ragunan dan Taman Margasatwa Bandung dan waktu pelaksanaan kegiatan berlangsung pada Desember 2016 - Februari 2017.

\section{ALAT DAN BAHAN PENELITIAN}

Blanko penilaian kesejahteraan satwa berdasarkan peraturan Direktur Jenderal perlindungan hutan dan konservasi alam nomor: P.6/IV/-SET/2011, alat tulis dan alat recording (Handphone recorder; Samsung ace 2), serta pengambilan gambar dengan kamera Nikon L820.

\section{METODOLOGI PENELITIAN}

Metode penelitian yang digunakan adalah metode observasi, dengan melakukan pengamatan lapangan serta wawancara terhadap petugas pengelola lembaga konservasi. Data penelitian berupa hasil penilaian borang yang mencakup 5 kebebasan dari satwa sesuai dari peraturan Direktur Jenderal perlindungan hutan dan konservasi alam, nomor: P.6/IV/-Set/2011, tentang pedoman etika dan kesejahteraan satwa di lembaga konservasi (Five freedom).

\section{TEKNIK ANALISIS DATA}

Data berupa skor borang 5 (lima) kebebasan satwa diuji statistik non parametrik dengan uji Mann Whitney, 
menggunakan software SPSS 16.0, untuk menganalisis pengaruh nilai pengelolaan di dua lembaga konservasi terhadap kesejahteraan Panthera tigris sumatrae.Hasil akhir penilaian berupa skor rata-rata di setiap lembar borang penilaian kesejahteraan satwa, dihitung dengan rumus

$$
\frac{\sum \text { skor tiap kriteria }}{\sum \text { soal }} \times 100 \%
$$

\section{HASIL DAN PEMBAHASAN}

\section{KONDISI HARIMAU SUMATERA}

Harimau Sumatera yang ada di Ragunan berjumlah 25 ekor, terdiri dari 10 jantan dan 15 betina. Taman Margasatwa Ragunan terdiri dari kandang area timur dan utara dengan luas kandang rata-rata adalah $708 \mathrm{~m}^{2}$ atau sekitar 28,5 m²/ekor harimau Sumatera, dan harimau Sumatera yang ada di TM Bandung berjumlah 4 ekor, terdiri dari 1 betina dan 3 jantan. Umur rata-rata harimau di Bandung sekitar 17 tahun. Luas total area kandang harimau Sumatera di TM Bandung adalah $200 \mathrm{~m}^{2}$ atau sekitar $50 \mathrm{~m}^{2} /$ individu harimau Sumatera.

Tabel 4. Jenis dan jumlah pakan yang diberikan

\begin{tabular}{l|l|l|}
\hline $\begin{array}{l}\text { Nama pakan } \\
\text { A. Jumlah harimau }\end{array}$ & $\begin{array}{c}\text { Bandung } \\
\text { B ekor }\end{array}$ & $\begin{array}{c}\text { Ragunan } \\
25 \text { ekor }\end{array}$ \\
$\begin{array}{l}\text { B. Jenis Pakan } \\
\text { 1. Daging sapi }\end{array}$ & \\
2. Daging babi & $2 \mathrm{~kg}$ & $45 \mathrm{~kg}$ \\
3. Daging ayam & - & $72 \mathrm{~kg}$ \\
Total pakan & $16 \mathrm{~kg}$ & $39 \mathrm{~kg}$ \\
\hline
\end{tabular}

\section{PENGELOLAAN KESEJAHTERAAN HARIMAU SUMATERA}

\section{Aspek Bebas Dari Rasa Lapar dan Haus}

Praktek pengelolaan aspek bebas dari rasa lapar dan haus berdasarkan pakan dan kebutuhan air yang diberikan oleh pengelola, sesuai dengan standar atau tidak sesuai dengan standar pengelolaannya. Dalam praktik pengelolaannya sudah baik, hal ini ditandai dengan pemberian pakan yang sesuai dengan pakan yang harimau Sumatera dapatkan di alam, seperti daging babi dan daging sapi. Asumsi untuk bahan kebutuhan pakan harian suatu jenis satwa adalah 10\% dari bobot badannya (Anggraini, 2010), maka kebutuhan pakan untuk individu dewasa harimau Sumatera dengan asumsi berat badan ideal harimau $60 \mathrm{~kg}$ adalah sebanyak $6 \mathrm{~kg}$.

Asumsi untuk bahan kebutuhan pakan harian suatu jenis satwa adalah 10\% dari bobot badannya (Anggraini, 2010), maka kebutuhan pakan untuk individu dewasa harimau Sumatera dengan asumsi berat badan ideal harimau $60 \mathrm{~kg}$ adalah sebanyak 6kg. Syarat pakan bagi satwa diantaranya adalah pakan harus bersih, segar, dan bebas dari kontaminasi, cocok, dan sesuai dengan selera satwa, tidak menimbulkan gangguan metabolisme, pakan harus dalam jumlah yang cukup, mutu baik, seimbang, dan bervariasi (Dirjen PHKA, 2011).

Air menjadi kebutuhan yang sangat penting bagi satwa, karena digunakan untuk minum. Air yang disediakan di kandang harimau Sumatera ; a). Kandang istirahat dan, b). Kandang peraga mencukupi kebutuhan satwa, karena untuk satu kandang harimau Sumatera, mempunyai sumber air sendiri. Kualitas air yang baik adalah adalah air dengan ukuran pH normal, yaitu pH 6 (Gambiro, 2012). Berdasarkan hasil pengamatan, air yang disediakan oleh TM Ragunan tersedia dengan jumlah yang banyak dan selalu ada, serta air yang ada di dalam kandang harimau Sumatera 
diganti setiap 1 (satu) minggu sekali. TM Bandung, air yang disediakan selalu ada, hanya saja pemberian air terhadap satwa kurang, dan air didalam kandang peraga tidak sering diganti, air sangat kotor, dan ditambah beberapa sampah yang tidak dibersihkan petugas.

Tabel 6. Aspek bebas dari ketidaknyamanan suhu dan fisik

\begin{tabular}{|c|c|c|c|}
\hline Parameter & Ragunan & Bandung & Keterangan \\
\hline \multirow[t]{3}{*}{ Suhu } & $\pm 26,5^{\circ} \mathrm{C}$ & $\pm 25^{\circ} \mathrm{C}$ & Kandang tidak mendapatkan cahaya \\
\hline & & & matahari yang cukup, kandang gelap \\
\hline & & & (Bandung) \\
\hline \multirow[t]{3}{*}{ Kelembapan } & $\pm 85 \%-90 \%$ & $\pm 60 \%-75 \%$ & Kandang terbuka dan mendapatkan \\
\hline & & & banyak pencahayaan matahari yang baik \\
\hline & & & (Ragunan). \\
\hline
\end{tabular}

\section{Aspek Bebas Dari Ketidaknyamanan Suhu dan Fisik}

Aspek bebas dari ketidaknyamanan suhu dan fisik dapat diketahui dengan melihat kondisi suhu, kelembapan, bahan pembuat kandang, dan kebersihan kandang. Kondisi suhu dan kelembapan kandang merupakan salah satu aspek penting yang terkait rasa nyaman bagi satwa.

Sistem perkandangan merupakan elemen yang penting dalam mendukung fisik dan sosial satwa (Riptianingsih,2014).

Beberapa faktor yang mempengaruhi ketidaknyamanan pada satwa diantaranya adalah suhu, kelembapan, intensitas cahaya, dan keterediaan air. Suhu kandang merupakan salah satu aspek penting terkait rasa nyaman satwa (Anggraini, 2015). Pada TM Ragunan, suhu kandang rata-rata $26,5^{\circ} \mathrm{C}$ dan kelembapan rata-rata $85 \%-90 \%$. Hal ini berbeda dengan TM Bandung yang suhu rata-rata kandang adalah $25^{\circ} \mathrm{C}$, dan kelembapan rata-rata sebesar $60 \%$ $75 \%$. Suhu di alam yang membuat harimau nyaman berkisar antara $24^{\circ}-27^{\circ} \mathrm{C}$, dan kelembapan di alam berkisar $86 \%$ $95 \%$.

Tabel 7. Jenis, gejala, dan pengobatan terhadap harimau Sumatera di Taman margasatwa Ragunan dan Bandung

\begin{tabular}{lll}
\hline Penyakit dan luka & Gejala penyakit /luka & Pengobatan \\
\hline Diare & Satwa tidak nafsu makan dan kotorannya & Pemberian antibiotik dan anti-diare, yaitu \\
& berupa cairan. & Mebendazole \\
Infeksi pencernaan & Dipermukaan feses satwa, terapat cacing & Obat yang diberikan adalahKalbazen \\
\hline
\end{tabular}

Kandang harimau Sumatera di Bandung memiliki kelembapan yang tinggi karena, hal ini ditandai dengan kondisi kandang di TM Bandung yang kurang baik dalam mendapatkan pencahayaan matahari karena terlalu kurang ventilasi yang diberikan, sehingga menjadikan kandang kurang kondusif, kandang menjadi lembab, sedangkan di Ragunan, kandang sangat terbuka dan mendapatkan pencahayaan matahari yang baik. Cahaya matahari berpengaruh terhadap alur metabolisme makhluk hidup, meminimalisasi jamur dan atau penyakit yang akan menjangkit satwa. Praktik pengelolaan aspek bebas dari ketidaknyamanan suhu dan fisik di TM Bandung relatif belum sesuai dengan kondisi alamiah yang dibutuhkan harimau Sumatera, sedangkan bernilai baik di TM Ragunan, hal ini ditandai dengan kondisi kandang sangat baik, ventilasi pada kandang, naungan untuk melindungi satwa dari cuaca buruk ada dan sangat menunjang perilaku alami harimau Sumatera.

Suhu, kelembapan, dan cahaya matahari, sangat berpengaruh terhadap aktivitas harimau Sumatera di dalam 
kandang, karena pada saat suhu panas, harimau Sumatera cenderung diam dan tidak melakukan banyak aktivitas. Faktor-faktor yang dapat mempengaruhi suhu didalam kandang diantaranya adalah intensitas sinar yang masuk kedalam kandang, produksi panas dari tubuh satwa, dan kondisi konstruksi kandang. Ada faktor penting lainnya bagi kesejahteraan harimau Sumatera yaitu bersih atau tidaknya kandang. Kandang dibersihkan dengan air yang diberi desinfektan untuk membersihkan kandang dari sisa pakan dan kotoran. Kebersihan kandang di TM Ragunan dan TM Bandung, dibersihkan dengan baik, hal ini sesuai dengan Anggraini (2015), Pembersihan kandang minimal dilakukan satu kali dalam sehari.

Tabel 8. Jenis pengayaan kandang harimau Sumatera di TM Ragunan dan TM Bandung

\begin{tabular}{lll}
\hline Penyakit dan luka & Gejala penyakit /luka & Pengobatan \\
\hline Diare & Satwa tidak nafsu makan dan & Pemberian antibiotik dan anti-diare, yaitu \\
& kotorannya berupa cairan. & Mebendazole \\
Infeksi pencernaan & $\begin{array}{l}\text { Dipermukaan feses satwa, } \\
\text { terapat cacing }\end{array}$ & Obat yang diberikan adalah Kalbazen \\
& & \\
\hline
\end{tabular}

\section{Aspek Bebas Dari Rasa Sakit, Penyakit dan Luka}

Selama masa pengamatan diketahui tidak adanya tanda-tanda harimau Sumatera yang sedang sakit. Pengecekan kesehatan dilakukan oleh perawat satwa setiap 3 kali seminggu. Pengecekan dilakukan dengan melihat kotoran dan sisa makanan harimau Sumatera. Pemeriksaan yang dilakukan oleh dokter hewan berdasarkan laporan perawat satwa/keeper. Hasil wawancara terhadap perawat satwa diketahui bahwa penyakit yang pernah diderita harimau Sumatera diataranya adalah infeksi cacing dan diare di TM Ragunan dan TM Bandung.

Menurut PKBSI (2000), fasilitas kesehatan satwa meliputi bangunan rumah sakit, klinik, atau ruang rawat, ruang laboratorium, ruang karantina, ruang isolasi, tenaga dokter hewan dan medis. Berdasarkan hasil yang diperoleh manajemen kesehatan harimau di TM Bandung cukup baik, dikarenakan TM Bandung masih memperbarui kualitas perawatan dalam manajemen kesehatan satwa. Sedangkan di TM Ragunan majemen kesehatannya sangat baik, karena di TM Ragunan Fasilitas medis mencukupi, fasilitas medis di TM Ragunan diantaranya adalah laboratorium parasit, ambulance, laboratorium darah, rontgen, USG, ruang operasi, mesin anestesi, dan gudang obat yang terjaga kebersihannya.

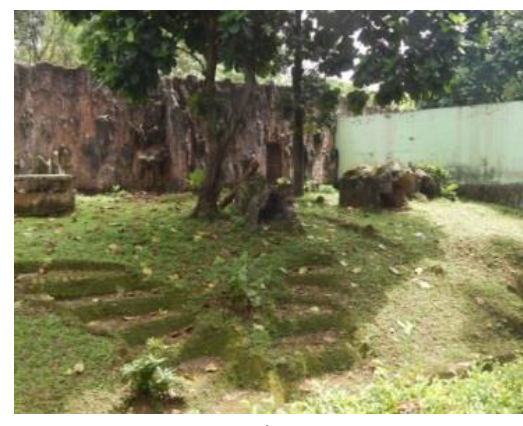

A

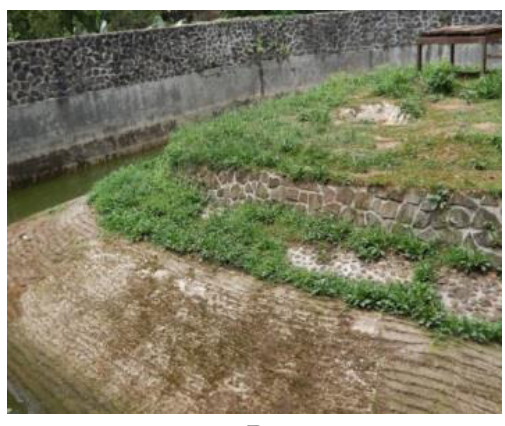

B

Gambar 7. Pengayaan kandang a). TM Ragunan, dan b). TM Bandung

Pencegahan penyakit dapat dilakukan melalui penanganan aspek pengandangan dan pemberian makan yang baik (Mcardle, 1972 dalam Trisaputra, 2009). Adapun tindakan pencegahan penyakit sekaligus untuk meningkatkan daya tahan tubuh harimau Sumatera diberi vitamin dan obat. Vitamin yang dierikan yaitu B complex, vitamin C, Neurobion, dan vitamin lainnya. 
Fasilitas medis yang terdapat di lokasi penelitian adalah laboratorium parasit, ambulance, laboratorium darah, rontgen, USG, ruang operasi, mesin anestesi, dan gudang obat yang terjaga kebersihannya. Aspek bebas dari penyakit dan rasa sakit bernilai baik yang ditandai dengan adanya pemeriksaan kesehatan rutin. Bebas dari rasa sakit, luka, dan penyakit adalah pencegahan, pengobatan, dan perawatan cepat terhadap penyakit, dan luka pada satwa (FAWC, 2009). Ada beberapa penyakit yang sangat mudah menyerang harimau Sumatera, diantaranya bisa terlihat pada Tabel 7.

Tabel 8. Hasil penilaian kesejahteraan harimau Sumatera di Ragunan dan Bandung

\begin{tabular}{|c|c|c|c|c|c|}
\hline \multirow{2}{*}{ Prinsip Kesejahteraan } & \multicolumn{2}{|l|}{ Skor } & \multirow[t]{2}{*}{ Skor Maksimum } & \multicolumn{2}{|c|}{ Presentase } \\
\hline & $\mathrm{R}$ & $\mathrm{B}$ & & $\mathrm{R}$ & $\mathrm{B}$ \\
\hline "Aspek bebas dari rasa Lapar dan haus" & 67 & 58 & 75 & $89 \%$ & $77 \%$ \\
\hline "Aspek bebas dari ketidaknyamanan suhu dan fisik" & 35,2 & 27,8 & 50 & $70 \%$ & $55 \%$ \\
\hline "Aspek bebas dari rasa sakit, penyakit, dan luka." & 63,6 & 50,1 & 90 & $71 \%$ & $57 \%$ \\
\hline "Aspek bebas bertingkah Laku normal" & 45,6 & 42,5 & 60 & $76 \%$ & $70 \%$ \\
\hline "Aspek bebas dari rasa Takut dan menderita" & 31 & 21,8 & 40 & $77 \%$ & $54 \%$ \\
\hline Rata-rata & & & & $77 \%$ & $60 \%$ \\
\hline Kriteria Penilaian & & & & Bak & Cukup \\
\hline
\end{tabular}

\section{Aspek Bebas Bertingkah Laku Alamiah}

Taman margasatwa sebagai salah satu lembaga konservasi yang melindungi satwa liar, diperlukan sarana dan prasarana yang sesuai dan lazim mendukung harimau Sumatera dapat berperilaku alamiah sesuai dengan habitat aslinya, maka di dalam kandang diperlukan pengayaan kandang (enrichment), seperti pada Tabel 8.

Pengayaan kandang di kedua taman margasatwa bernilai baik dan cukup, sesuai dengan kebutuhan harimau Sumatera dalam melakukan aktivitasnya. Bebas berperilaku alami merupakan kebebasan satwa untuk berperilaku sama seperti habitat alaminya (Ecclestone, 2009).

Pengayaan kandang harus cukup kuat dan tahan lama untuk digunakan sehari-hari oleh harimau Sumatera (COP, 2013). Posta et al. (2013), menambahkan bahwa fasilitas kandang terbuka dilakukan dengan membuat pengayaan berupa substrat pasir pada lantai kandang, kolam yang cukup dalam, adanya pepohonan, dan berbagai tumpukan batang kayu.

Berdasarkan hasil pengamatan, enrichment pada TM Ragunan lengkap, semua hal yang dibutuhkan oleh harimau Sumatera tersedia, hanya saja penggantian/ketika ada yang rusak adanya keterlambatan perbaikan, seperti shelter/clover pada kandang peraga rusak, waktu perbaikan yang dibutuhkan lambat, sedangkan di TM Bandung, vegetasi pohon kurang, hanya vegetasi rumput/herba yang terlihat, karena seharusnya adanya pepohonan dan tumpukan batang kayu. Selain itu, salah satu kandang di TM Bandung tidak memiliki shelter/clover. Shelter/clover berfungsi sebagai tempat berlindung bagi satwa, sebagai pencegah pengeluaran energi yang berlebihan pada satwa, tempat berlindung satwa dari cuaca buruk, dan predator (Bolen, dan Robinson, 2003).

\section{Aspek Bebas Dari Rasa Takut dan Menderita}

Hasil wawancara dari perawat satwa diketahui bahwa pengelolaan yang dilakukan pada aspek bebas dari rasa takut dan menderita antara lain penanganan satwa yang baru datang dan penanganan satwa yang mengakibatkan satwa mengalami stres. Kondisi harimau Sumatera di TM Ragunan tidak ada yang mengalami rasa takut dan menderita. Harimau Sumatera pada di TM Ragunan sudah bisa beradaptasi dengan baik yang ditandai dengan kemampuan menghasilkan keturunan. Jordan (2005) menyatakan stres pada satwa dapat terjadi saat satwa mengalami fisik dan emosi terganggu. 
Harimau Sumatera di TM Bandung menunjukkan gejala stres. Keadaan harimau Sumatera di TM Bandung berdasarkan hasil wawancara dengan pengelola, kondisi tubuhnya sudah tua, umur harimau Sumatera rata-rata \pm 16 tahun. Selain itu, menurut tim pengelola, harimau Sumatera di TM Bandung juga dalam keadaan overweight, oleh karena itu ada saat dimana makanan yang harusnya $6 \mathrm{~kg} /$ individu dikurangi sampai $1,5 \mathrm{~kg}$ dari jatah makan seharusnya.

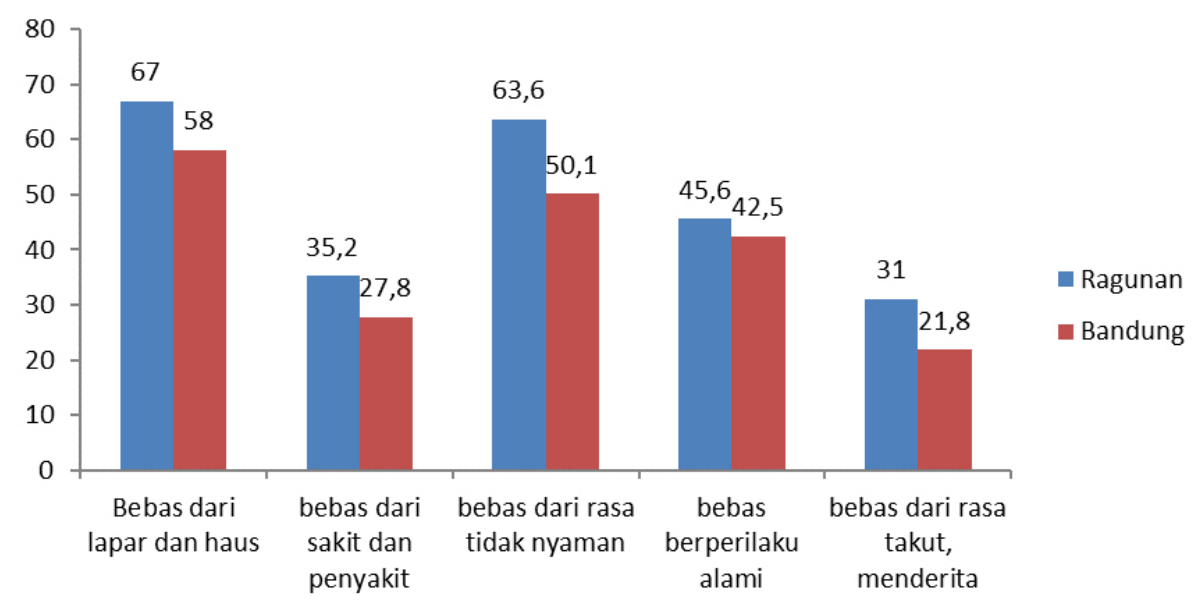

Grafik 1. Kesejahteraan harimau Sumatera di TM Ragunan dan TM Bandung

Keadaan harimau Sumatera di TM Ragunan baik, dan berat badannya tidak overweight. Pakan selalu diberikan dengan tepat waktu dan sesuai kadarnya, yaitu $6 \mathrm{~kg} /$ individu. Jika mengalami stres, harimau Sumatera menunjukkan tanda stresnya dengan tidak nafsu makan, dan mengeluarkan suara harimau berlebihan. Hal ini dikarenakan adanya kegiatan yang tidak sengaja berakibat tidak baik untuk perilaku harimau Sumatera, seperti pembersihan kandang atau perbaikan kandang dan pemeriksaan kesehatan. Bebas dari rasa takut dan menderita adalah jaminan kondisi dan perlakuan satwa yang baik untuk menghindari satwa dari ancaman takut dan stres (Encclestone, 2009).

\section{TINGKAT KESEJAHTERAAN HARIMAU SUMATERA}

Berdasarkan kriteria penilaian kesejahteraan satwa, hasil yang didapatkan adalah TM Ragunan bernilai baik dengan nilai 77\% dan TM Bandung bernilai cukup dengan nilai 60\%. Hasil uji Mann Whitney diperoleh nilai $\alpha$ $0,03<0,05$. Hal ini berarti terdapat perbedaan tingkat kesejahteraan harimau Sumatera pada TM Ragunan dan TM Bandung, sesuai pada Tabel 8.

Berdasarkan tabel 8 diatas, kriteria kesejahteraan harimau Sumatera di TM Ragunan dan TM Bandung adalah baik dan cukup. Kriteria penilaian tersebut terlihat pada grafik dibawah ini,:

\section{KESIMPULAN DAN SARAN}

\section{KESIMPULAN}

Pengelolaan harimau Sumatera pada kegiatan konservasi di penangkaran memiliki skor tingkat kesejahteraan 77\% (baik) di TM Ragunan dan memiliki nilai 60\% (cukup) di TM Bandung.

\section{SARAN}

Praktik pengelolaan yang perlu ditambah pada TM Bandung adalah perlunya dokter hewan dan tenaga 
medis yang berwenang dalam pemeriksaan kondisi satwa saat ada/tidak diperlukan pemeriksaan, sedangkan pada TM Ragunan perlu adanya tambahan kandang khusus untuk harimau Sumatera yang bunting dan akan melahirkan dan satu hal yang penting adalah memberikan informasi terhadap pengunjung agar tidak membuang sampah dan mengganggu satwa dan diperlukannya penelitian lebih lanjut mengenai kesejahteraan satwa.

\section{DAFTAR PUSTAKA}

Borner, M. 1978. Status and conservation of Sumatran tiger. Carnivore I. 97-102.

Broom D.M. 1991. Assessing welfare and suffering. Behavioral Processes, (25) : 117-123.

Eccleston, KJ. 2009. Animal Welfare di Jawa Timur; Model Kesejahteraan Binatang Jawa Timur. Malang: Universitas Muhammadiyah Malang

Matthews, R. 1989. How They Live. Tiger. Mallard Press, New York.

Hoeve B V. 2003. Ensiklopedi Indonesia Seri Fauna Mamalia. PT Dainipon Printing Indonesia ; Jakarta.

World Wild Life Foundation. 2007. Harimau Sumatra. http://www.worldwildlife.org/species/sumatran-tiger (1 Juni $\underline{2016) .}$

Jordan, B. 2005. Science Best Assessment Of Animal Welfare: Wild and Captive Animals. Rev. sci. tech. Off. Int. Epiz. $24(2): 515-528$

Peraturan Menteri Kehutanan Republik Indonesia. 2012. Lembaga Konservasi. (UU ; P.31/Menhut/-II/2012).

[PKBSI] Perhimpunan Kebun Binatang Se-Indonesia. 2000. Pengelolaan Taman Satwa di Indonesia. Jakarta (ID): PKBSI

Santiapillai ch, dan W.S Rahmono. 1985. On The Status of Tiger (Panthera tigris Sumatra) in Sumatra. Tiger Paper $12(1) ; 23-28$.

[TMR] Taman Margasatwa Ragunan. 2016. Pusta Primata Schemutzer. http://ragunanzoo.jakarta.co.id [20 November 2016]

The IUCN Red List of Threatened Species. 2007. Panthera tigris Sumatra. http://www.iucnredlist.org/ details/15966/0 (1 Juni 2016)

Tumbelaka, Ligaya. 2004. Penangkaran Harimau Sumatera. PKBSI di Taman Safari Indonesia, Bogor.

Vaughan, T.A. 1986. Mammalogy. $3^{\text {rd }} \mathrm{ed}$. Saunders College Publishing, Arizona : $576 \mathrm{hlm}$.

Wibisono, HT., and Wulan pusparini. 2010. Sumatran tiger (Panthera tigris sumatrae): A review of conservation status. Integrative Zoology 5, no. 4 : 313-323. 